\title{
PRELIMINARY MORPHOLOGICAL ANALYSIS OF LOCAL DURIAN (DURIO ZIBETHINUS MURR.) OF CRIWIK REGION (CENTRAL JAVA, INDONESIA)
}

\author{
Andini Desi SAWITRI, Endang YUNIASTUTI, NANDARIYAH \\ Agronomy Program, Sebelas Maret University in Surakarta, 57126, Indonesia \\ e-mail: andini.dessi@gmail.com \\ yuniastutisibuea@staff.uns.ac.id
}

\begin{abstract}
Indonesia has become one of the centres of genetic diversity of durian, but studies about superior local durian are still limited, so a study of morphological analysis is required to obtain potentially superior durians. This research aims: 1) To understand the morphological diversity of some local Criwik durians; 2) To obtain information about local durian that has potential characters as a superior local durian of Criwik Region. This research used descriptive explorative research method with sampling taken by purposive random sampling. The morphological character observations were made on both vegetative and reproductive organs and then analyzed using NTSYS 2.02. Based on this research, vegetative analysis revealed 10 accessions of durian that have morphological differences. In reproductive organ analysis we found local durians with distinctive superior properties.
\end{abstract}

Keywords: Genetic diversity, superior durian, Indonesian durian, morphological analysis, plant breeding, plant germplasm.

\section{Introduction}

Durian (Durio zibethinus Murr.) is one of the tropical fruits of high economic value [7]. It is one of the most popular and famous seasonal fruits in South-east Asia, as well as the source of carbohydrates, proteins and vitamins B and C [10,3]. The demand for durians from the overseas market increases from year to year, and nowadays domestic and overseas consumers are targeting local durians because of the many local varieties that have superior qualities [17].

The problem that currently arises is that absence of regeneration causes durian crops to be only a relictual heritage, so some local durian varieties begin to be rarely found [17]. In addition, rural communities and governments have difficulties in developing local varieties due to the lack of information to develop these local durian varieties, such as those occurring in Rembang regency.

Rembang regency is one of the regencies (rural administrative districts) in Central Java province that has a large local diversity of durians, especially in Criwik village, a durian tourist centre. On the other hand, information related to local cultivars is limited, because the diversity of the durian trees in Rembang district has not been studied before. According to Yuniastuti (2009), limited genetic information can be an obstacle in the development of durian breeding, as it can inhibit the determination of the method or direction of plant breeding. Further research on the potential of local durian germplasm is needed to obtain information on potentially superior durian cultivars through character analysis and plant selection based on morphological 
characters.

\section{Materials and Methods}

Location and Time Research

This research was conducted from July 2017 to December 2017 in Criwik Village, Pancur District in Rembang Regency, Central Java.

Research Design and Data Analysis

This research used descriptive exploratory research methods with morphological identification on vegetative and reproductive organ characters of Descriptors for Durian plants [1]. The 10 durian samples were obtained by purposive random sampling, using the type of snowball sampling in which the sample point was based only on local durian plants that had fruited. Each sample of durian found was numbered and named by the durian tree owner's name.

Morphological data analysis used Numerical Taxonomic and Multivariate System NTSYS-pc. 2.02. Each character was divided into sub-characters that showed the differences and then converted in the form of binary data. The sub-characters which appeared were given a score of 1 and those that did not appear given a score of 0 [4]. The analysis to make a similarity matrix was carried out by the SIMQUAL (Similarity for qualitative data) procedure. Moreover, it was continued on SAHN (Sequential Agglomerative, Hierarchical and Nested) analysis with the UPGMA (Unweighted Pair Group Method with Arithmetic Average) method and similarity matrix using the DICE coefficient [9].

\section{Results and Discussion}

Morphology of vegetative organs

From the results of field observations that have been made on 10 accessions in Criwik village, it is known that there are two types of canopy crown shape, a pyramid-shaped header found in 1 accession and an irregular shape in 9 accessions (Figure 1). The canopy crown of the durian tree (Durio zibethinus Murr.) comprises a pyramidal, oval, round, wider, elliptical or irregular shape [13].

Observation of branch growth performed on 10 durian accessions showed that 9 of the accessions had spreading branches, while the growth of intermediate branches was present in only 1 accession (Figure 2). The surface of the stems of 10 durian accessions revealed 4 accessions in rough categories and 6 accessions in the very rough category. Durian bark is generally rough because there is a corky crust. In the main stem grows a primary branch to the side that alternates without a pattern to the top of the plant [15].

Based on the observations of stem colour, 6 accessions were found to have brown colour and 4 others to have dark brown colour. All stems of 10 plant accessions had a diameter of 20-57 $\mathrm{cm}$. The diameter is influenced by the age of the plant, which is directly proportional to the diameter. Besides, the availability of food depends on the width of the stem diameter that is proportional to the amount of available food reserved [16].

Observation of the vegetative organs was also made, on the leaves. The results of these observations are presented in Figure 3. It was found that 7 accessions had an elliptical (rounded long) leaf shape and 3 accessions an oblong leaf shape. As regards the leaf apex there was 1 accession with an acuminate leaf apex and there were 9 accessions with a long-acuminate leaf apex. The shape of the leaf base was found to be cuneate in 9 accessions and acute in 1 
accession. All accessions observed had the same glossy upper leaf surface; the lower surface was not glossy. The leaf margin of all samples was entire. Sunaryo et al. (2015) [14] also found that there were no differences of leaf margin in Durio zibethinus Murr.

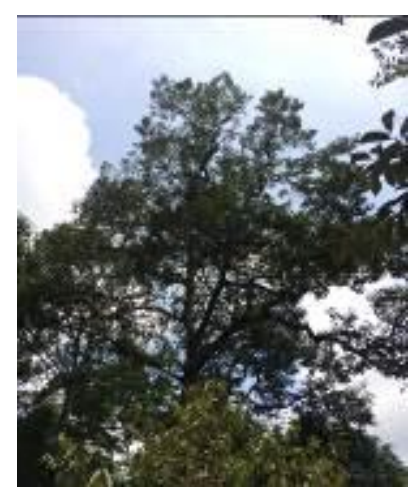

a

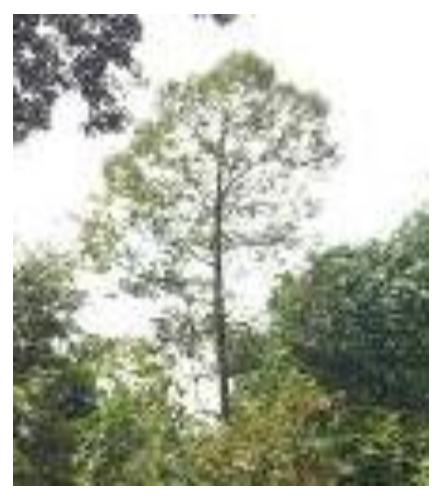

b

Fig. 1: a. Irregular header b. Pyramidal header
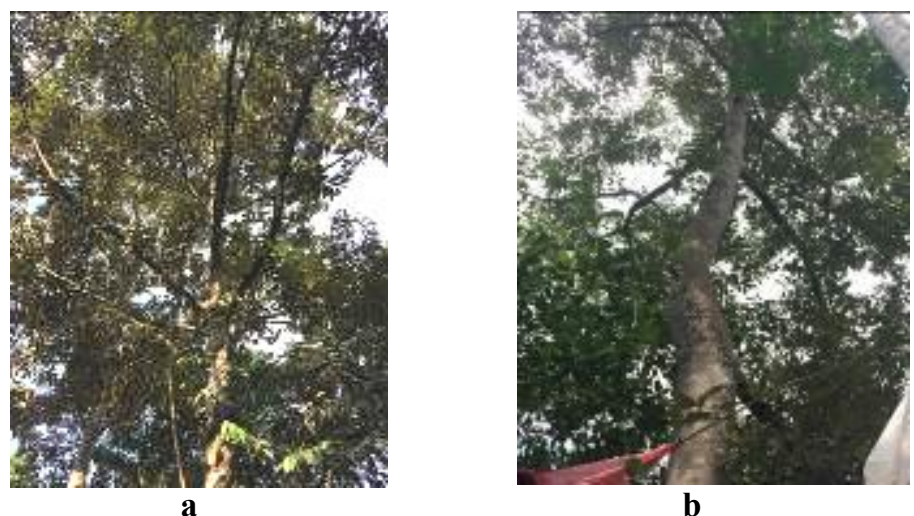

Fig. 2: a. Spreading branch growth b. Medium branch growth

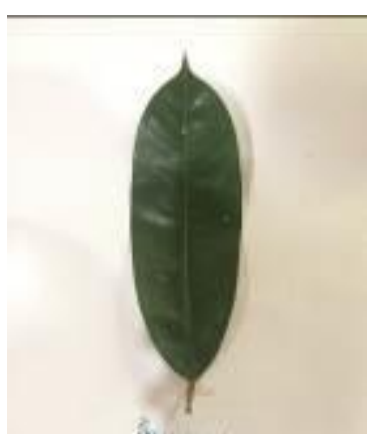

a

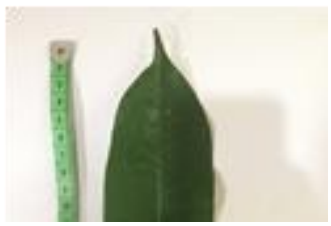

c

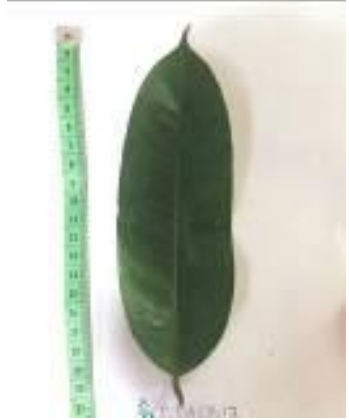

b

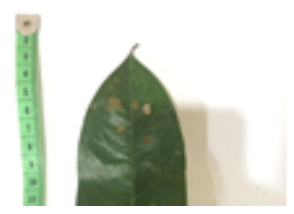

d

Fig.3: a. Oblong leaf blade shape; b. Elliptical leaf blade shape; c. Long-acuminate leaf apex shape; d. Acuminate leaf apex shape 
The colour of the leaves was observed to be dark green in 9 accessions and green in 1 accession. This is due to differences in the chlorophyll pigment content.

\section{Morphology of reproductive organs}

The reproductive organs observed included flowers, fruits and seeds. These observations of reproductive organ morphology included flower and fruit characters, presented in Figure 4. Observations were made on 4 durian accessions. This was because only 4 out of 10 accessions produced fruit. The factor that causes durians not to produce fruit is pollination failure [2]. The observations revealed flower buds of ovoid and globose shape with a cream-coloured crown in all accessions. The form of the durian flower buds was cauliflorous and they appeared in clusters. Each cluster, a cymose inflorescence, consisted of mostly 20 to 30 flower buds. Two or three pedicels diverged at the node of the peduncle [5]. Durian crown colour varied from white, beige and pink to deep red [15].

The shape of the fruit of 4 accessions had 4 types of globose (round), oblong (long), elliptical (elongate-round) and oval with a yellowish-green, green or orange yellow colour. The colours of the flesh of 4 accessions were creamy and lemon yellow. The total number of segments amounted to 5 and had the shape of oblong (elongate) and ellipsoid (elliptical) beans.

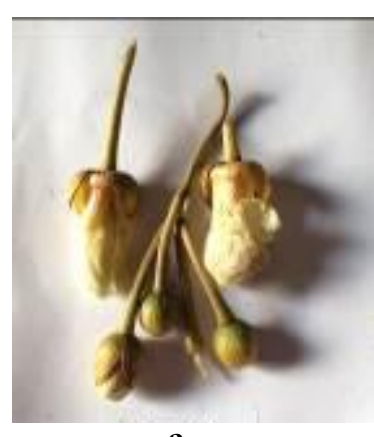

a

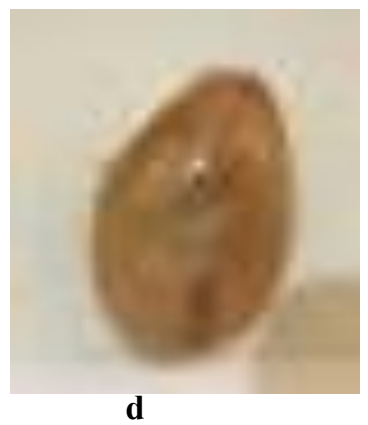

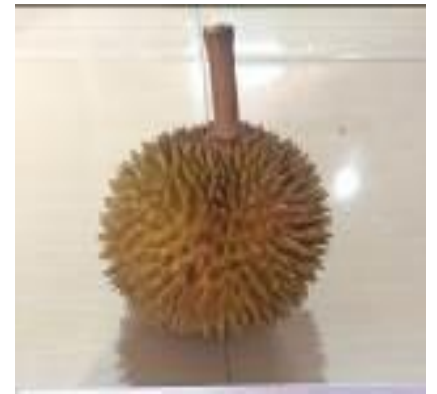

b

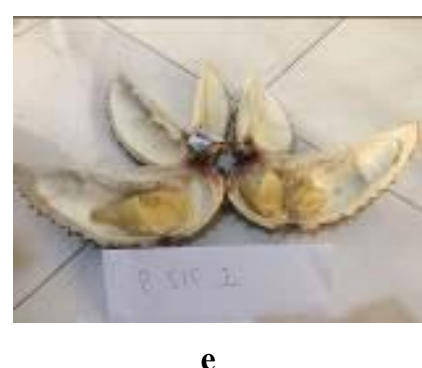

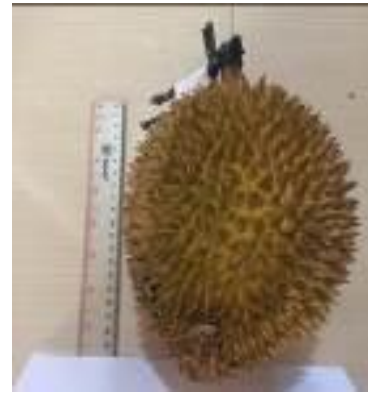

c

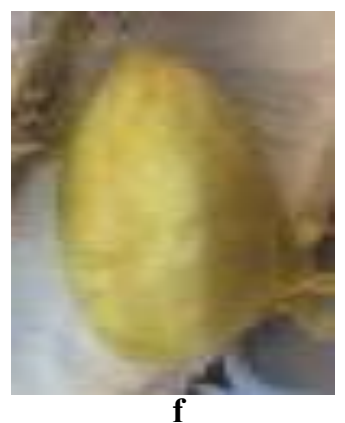

Fig. 4: a. Flower bud and flower blossom; b. Round fruit shape; c. Oval fruit shape; d. Ellipsoid seed shape; e. Durian segments; f. Fruit flesh

As regards the taste of the fruit flesh, 2 accessions were categorized as sweet and 2 as bitter-sweet, whereas the aroma of all accessions was moderate (medium). The volatile sulphur compound SVS has been identified as a major contributor to the unusual smell of durian. SVS is produced by the MGL gene through catalysis of methionine breakdown into SVS in microbes and plants [8].

Analysis of durian vegetative characters

The analysis of vegetative resemblance of durian is based on the morphological 
characters of the vegetative organ of durian in Descriptor of Durian, covering 1) plant character, i.e. age, plant height, crown shape, growth direction, and branching, 2) stem, i.e. rod texture, colour of stem, diameter of stem, 3) Leaf, i.e. leaf shape, leaf tip, leaf base, leaf margin, leaf surface, leaf length, leaf width, leaf colour, and leaf surface. The dendrogram of durian similarity based on morphological characters is presented in Figure 5.

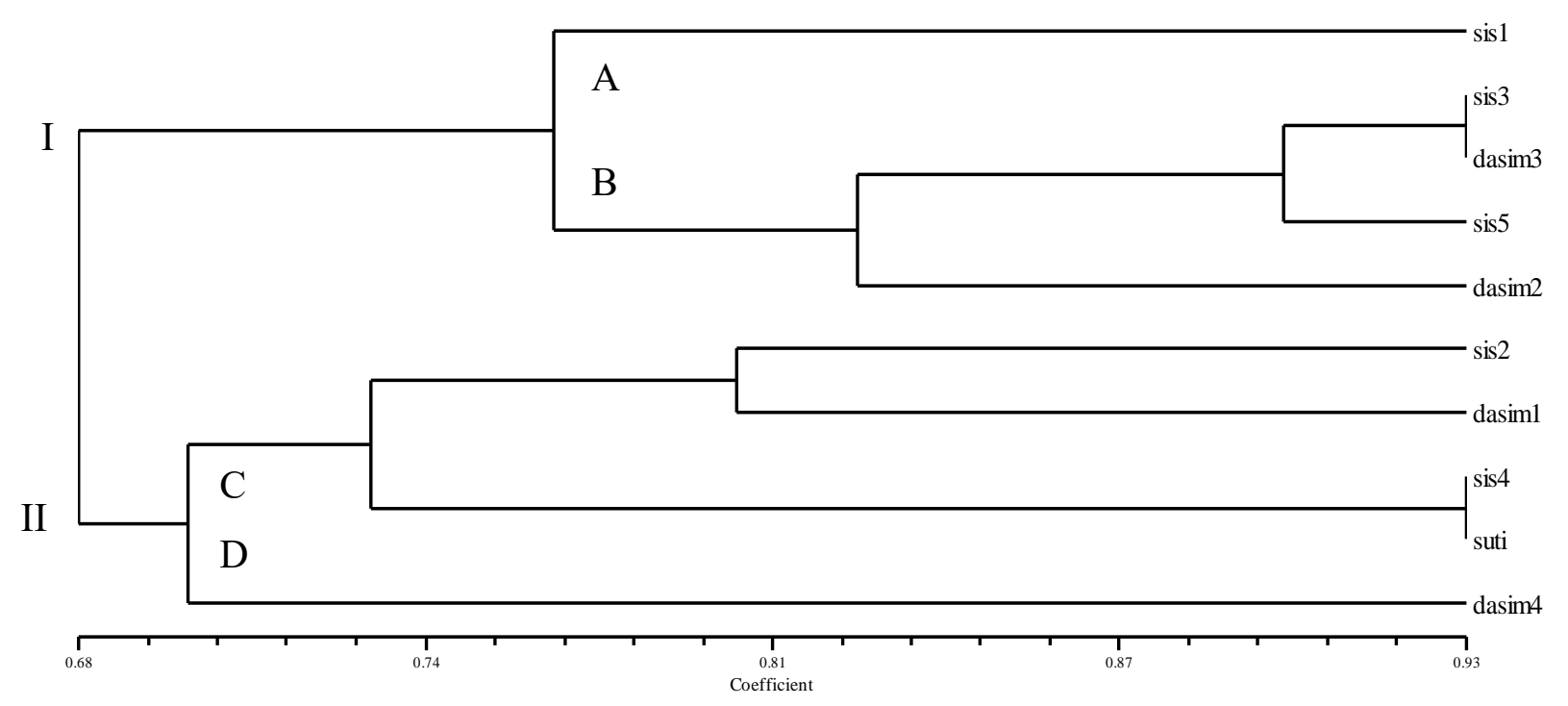

Fig. 5: Dendrogram grouping of vegetative organ characters

Based on the analysis of the vegetative similarities of 10 durian accessions, durians were divided into 2 major groups at the coefficient of similarity limitation of 0.68 or $68 \%$ with the coefficient matrix between accessions. Group 1 consists of groups A and B, while group 2 consists of groups $\mathrm{C}$ and D. Groups A and D have only one accession, whereas in group B and C consist of 4 accessions. Group B is divided into 2 more groups at the similarity coefficient limitation of 0.825 , which consists of sis 3 , dasim3, sis 5 and dasim 2 accessions. Group $\mathrm{C}$ is also divided into 2 groups on the similarity coefficient limitation of 0.725 consisting of sis 2 , dasim1, sis4 and suti accessions.

Durian sis 2 is a durian petruk variety that has similarities to the durian dasim 1 at the coefficient limitation of 0.80 . Durian sis 2 is a control or comparator because durian petruk has obtained the certificate of Local Variety Registration from the Center for Plant Variety Protection (PVT). In this case, durians that are different from durian sis 2 can be registered as local varieties.

The sis 3 and dasim 3 accessions have the highest level of similarity with the highest similarity coefficient of 0.93 or $93 \%$. Both of these accessions have similarities, such as the surface and colour of the stem, the shape of the canopy, branch growth, leaf shape, leaf margin, the tip and the base of the leaf and the leaf surface. It is also found in the accession sis 4 and suti.

Accessions that have a very low similarity level are dasim4, which has a difference in the shape of the crown header, which is pyramidal, while other accessions have an irregular crown shape. The base of dasim 4 accession leaves also has a difference compared to other acute-leaved accessions. Accessions that have the most differences need to be further investigated to find new cultivars. 


\section{Analysis of durian reproductive characters}

The higher the level of genetic variation, the more likely it is to obtain superior genotypes. Crossbreeding with relatively high genetic variations will produce individuals of higher heterozygosity [6].

Based on the scores data of 4 durian accessions, a dendrogram is obtained which forms two main groups. The coefficient of similarity ranges from 0.55 to 0.82 . The durian dendrogram is presented in figure 6 .

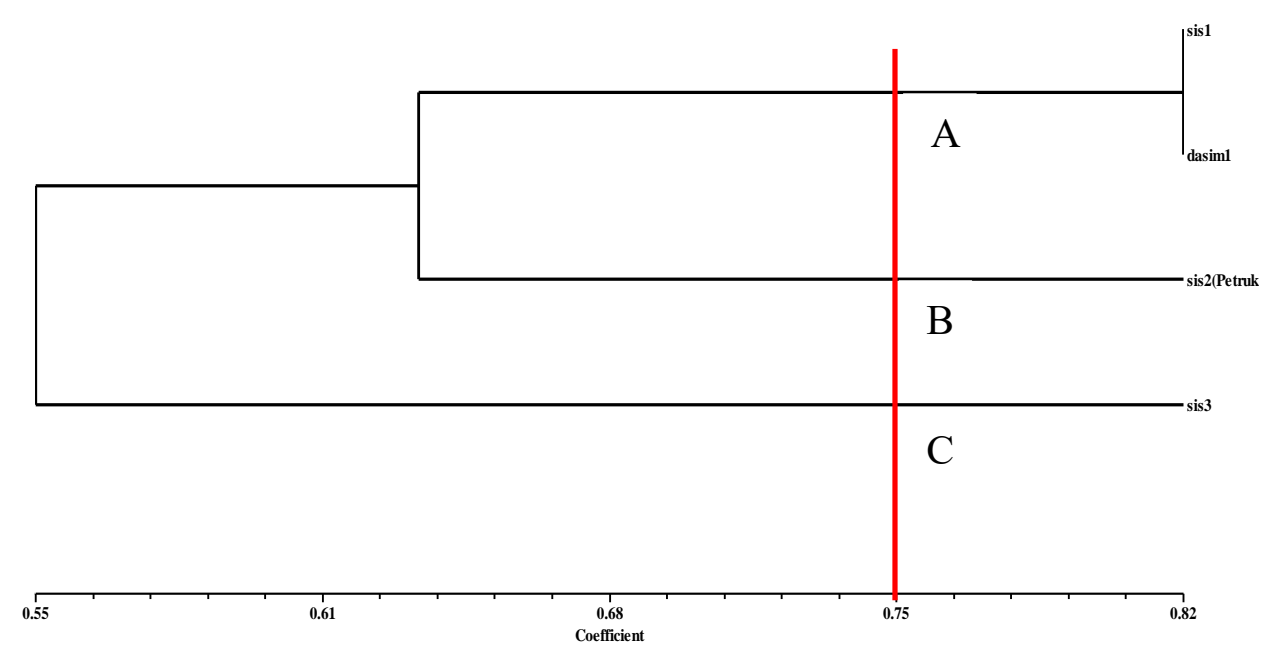

Fig. 6: Dendrogram of generative character organ grouping

Based on the dendrogram analysis, there are two large groups that are subdivided into three groups, namely A, B, and C, at the limitation coefficient of 0.75 . Group B and C have only 1 accession, whereas A has 2 accessions. Group A is divided into 2 accession members, namely sis 1 and dasim1, which have a high similarity coefficient of 0.82 . The differences are in the weight of the fruit, the rind of the ripe fruit, and the shape of the seed.

In the dendrogram results, accessions found that have more differences than other accessions are sis 3 . This is because, sis 3 accession has the limitation of the smallest similarity coefficient that is equal to 0.55 . Sis 3 accession has round fruit shape and orange yellow peel colour, so it has a distinct difference compared to other fruit.

\section{Superior local durian}

The dominant biophysical characters that determines the consumer to choose a durian are medium fruit size (1.6-2.5 kg), strong aroma, thick soft-textured and sweet, together with oval fruit shape, brownish green skin colour, medium thorn length, yellow flesh colour, and small seeds [11]. The result of observations on local durian fruit is presented in Table 1, below.

The analysis result from 4 accessions of local durian indicates that the fruit which is the closest to the consumer's choice is sis1. Sis1 accession has oval fruit shape, with yellow flesh colour. Sis 1 accession has a bitter-sweet taste with light weight and has an elliptical seed shape. The more easily separated segments of the fruit indicate that it is also of superior quality. 
Table 1: Observational data on four local durian fruit accessions

\begin{tabular}{c|c|c|c|c}
\hline Fruit character & Dasim1 & Sis1 & Sis2 & Sis3 \\
\hline Number of Fruits. & Combination & Combination & Combination & Combination \\
\hline Fruit Shape. & Oval & Oblong & Elliptic & Globose \\
\hline Weight of Fruit. & $1100 \mathrm{~g}$ & $600 \mathrm{~g}$ & $300 \mathrm{~g}$ & $530 \mathrm{~g}$ \\
\hline Old Skin Colour. & Greenish-yellow & Greenish-yellow & Green & Orange yellow \\
\hline Colour of Meat. & Lemon yellow & Creamy white & Lemon yellow & Lemon yellow \\
\hline Taste of Meat. & Bitter-sweet & Bitter-sweet & Bitter-sweet & Slightly sweet \\
\hline Fruit Aroma. & Moderate & Moderate & Moderate & Moderate \\
\hline Fruit Length. & $17 \mathrm{~cm}$ & $15 \mathrm{~cm}$ & $10 \mathrm{~cm}$ & $12 \mathrm{~cm}$ \\
\hline Fruit Circumference. & $44 \mathrm{~cm}$ & $37 \mathrm{~cm}$ & $31 \mathrm{~cm}$ & $37 \mathrm{~cm}$ \\
\hline Number of Segments. & 5 & 5 & 5 & 5 \\
\hline Seed Shape. & Elliptical & Oblong & Obovoid & Oblong \\
\hline
\end{tabular}

\section{Conclusions}

Based on the research results, it can be concluded on the basis of vegetative analysis, that 10 accessions of durian were found that have morphological differences with a coefficient of similarity limit between 0.68 and 0.93 ; and based on the basis of reproductive analysis that 4 accessions of durian were found that have morphological differences with a coefficient of similarity limit of $0.55-0.82$. In Criwik Region is also found a durian with superior qualities, namely sis 1 , because it has an oval fruit shape, with yellow flesh colour, bitter-sweet taste, light weight and an elliptical seed shape.

Acknowledgements: The authors' sincere thanks go to all local durian owners in Rembang for providing the research material.

\section{REFERENCES}

1. Biodiversity International, 2007, Descriptors for Durian (Durio zibethinus Murr.), International Plant Genetic Resource Institute (IPGRI), International Bioversity, Rome.

2. Bumrungsri, S., Sripaoraya, E., Chongsiri, T., Sridith, K., Racey, P.A., 2009, The pollination ecology of durian (Durio zibethinus, Bombacaceae) in southern Thailand, Journal of Tropical Ecology, 25: 85-92.

3. Consolacion, Y.R., Naomi, C,B., Bacar, Margarita, M.R., Querido, Carmen, M.S., Tan, Ramon, S., Fierro, D., Choi, J.S., 2016, Chemical Constituents of Durio zibethinus Murr. Fruit, International Journal of Pharmacognosy and Phytochemical Research, 8: 1300-1303.

4. Handayani, F., Wulandari, R.A., Murti, R.H., 2016, Genomic DNA Extraction Method From Mature Leaf Of Lai (Durio kutejensis Becc.), Agrivita, 38: 73-79.

5. Honsho, C., Yunemori, K., Sugiura, A., Somsri, S., Subhadhabadhu, S., 2004, Durian Floral Differentiation and Flowering Habit, Journal of the American Society for Horticultural Science, 129: 42-45.

6. Julisaniah, N.I., Sulistyowati, L., Sugiharto, A.N., 2008, Cucumber (Cucumis sativus L.) relationship analysis using RAPD-PCR and isozyme methods, Biodiversitas, 9: 99-102. 
7. Norjana, I., Aziah, A.A., 2011, Quality Attributes Of Durian (Durio zibethinus Murr.) Juice After Pectinase Enzyme Treatment, International Food Research Journal, 18: 1117-1122.

8. Patrick, T., Teh, B.T., Lim, K., Yong, C.H., Young, N.C.C., Rao, S.R., Rajasegaran, V., Lim, W.K., Ong, C.K., Chan, K., Cheng, V.K., Soh, P.S., Swarup, S., Rozen, S.G., Nagarajan, N., 2017, The draft genome of tropical fruit durian (Durio zibethinus), Natural Genetic, 49: 1633-1641.

9. Rohlf, F.J., 1998, NTSYSpc Numerical Taxonomy and Multivariate Analysis System Version 2.0 User Guide, Setauket, Applied Biostatistics Inc, New York.

10. Rudyansyah, Garson, M.J., 2006, Secondary Metabolites from the Wood Bark of Durio zibethinus and Durio kutejensis, Journal of Natural Products, 69: 1218-1221.

11. Santoso, Novaril, Anwarudinsyah, Wahyudi, Hasyim, 2008, Idiotipe Durian Nasional berdasarkan Preferensi konsumen, Jurnal Hortukultura, 18: 395-401.

12. Somsri, S., 2017, Production, diversity and utilization of durian in Thailand, Acta Horticultura, 1186: 1-14.

13. Sundari, Arumingtyas, E.L., Hakim, L., Azrianingsih, R., 2015, Exploration and Morphological Character Identification of Local Durian (Durio zibethinus Murr.) from Tidore Island, North Maluku, Paper presented at Proceedings of $6^{\text {th }}$ ICGRC, Brawijaya University, Indonesia.

14. Sunaryo, W., Hendra, M., Rudarmono, Suprapto, H., Pratama, A.N., Rahman, 2015, Exploration And Identification Of Lai Durian,New Highly Economic Potential Cultivars Derived From Natural Crossing Between Durio Zibethinus And Durio Kutejensis In East Kalimantan Asian, Asian Journal of Microbiology, Biotechnology \& Environmental Sciences, 17: 365-371.

15. Tirtawinata, M.R., Santoso, P.J., Apriyanti, L.H., 2016, DURIAN: Pengetahuan Dasar Bagi Pecinta Durian, AgriFlo, Jakarta.

16. Yuniastuti, E, Annisa, B.A., Nandariyah, Sukaya, 2017, Approach Grafting of Durian Seedling with Variation of Multiple Rootstock, Bulgarian Journal of Agricultural Science, 23: 232-237.

17. Yuniastuti, E., 2009, Phenotypic and Genotypic Characterization as well as In vitro Propagation of Durian Botanical Plants (Durio zibethinus Murr.), In: Karanganyar, Final Report of Competitive Grant Research for Fiscal Year 2008. LPPM UNS, Surakarta.

\section{ANALIZE MORFOLOGICE PRELIMINARE ASUPRA DURIANULUI DIN REGIUNEA CRIWIK (CENTRAL JAWA, INDONESIA)}

\section{(Rezumat)}

Indonezia a devenit unul dintre centrele de diversitate genetică pentru durian, dar studiile privind superioritatea durianului local sunt încă limitate., ca atare, în vederea evidenţierii potenţialului superior al durianului, un studiu de analiză morfologică este necesar. Acest studiu urmăreşte: 1. - să înţeleagă diversitatea morfologică a exemplarelor de durian din zona Criwik; 2. - să obţină informaţii despre potenţiale caractere de superioritate care definesc durianul din reiunea Criwik. Studiul de faţă foloseşte metode descriptiv-exploratorii de cercetare, utilizând mostre alese aleator. Observaţiile asupra caracterelor morfologice au fost efectuate atât pe organe vegetative, cât şi reproductive şi apoi analizate folosind NTSYS 2.02. Pe baza acestei prelucrări, analiza organelor vegetative a evidenţiat diferenţe morfologice la 10 exemplare de Durio zibethinus. De asemenea, analiza organelor reproductive a evidenţiat existenţa unor exemplare cu proprietăţi distinctive superioare. 